\title{
KAJIAN PENERIMAAN APLIKASI DROPBOX DALAM PEKERJAAN KELOMPOK SISWA: STUDI KASUS SMK SETIA NEGARA DEPOK
}

\author{
Dwi Yulistyanti \\ Fakultas Teknik Matematika dan Ilmu Pengetahuan Alam, Program Studi Teknik Informatika \\ Universitas Indraprasta PGRI Jakarta \\ Email: unindra.dwiyulist@gmail.com
}

\begin{abstract}
ABSTRAK
Salah satu teknologi baru mengalami perkembangan pesat teknologi komputasi awan (cloud storage). SMK Setia Negara Depok adalah sekolah kejuruan yang mempromosikan pengembangan dan penggunaan teknologi informasi untuk kegiatan belajar mengajar siswa. Oleh karena itu, sekolah merasa perlu untuk memperkenalkan media penyimpanan dan berbagi data pada siswa bahwa tidak ada hambatan untuk penyelesaian tugas, yaitu aplikasi Dropbox. Model yang digunakan dari Technology Acceptance Model (TAM) untuk menyertakan dua variabel eksternal, yaitu CSE dan TT dan 4 menerima variabel PEOU, PU, ATT dan IU untuk mengetahui aplikasi Dropbox penerimaan teknologi. Beberapa faktor yang dapat mempengaruhi atau moderasi antara jenis kelamin / seks dan tingkat / kelas. Pengambilan sampel menggunakan kuesioner dengan 176 responden. Metode pengolahan data menggunakan Model Structural Equation (SEM) dengan menggunakan AMOS 18.0. Dari hasil yang sudah di peroleh yaitu Para siswa/i SMK Setia Negara Depok sudah cukup siap dan menerima teknologi aplikasi Dropbox untuk digunakan menyelesaikan tugas kelompok siswa yang dijelaskan melalui hubungan kausal indeks terhadap penerimaan teknologi aplikasi Dropbox di SMK Setia Negara. Dengan jumlah responden yaitu 176 Ditinjau dari indentitas responden pada penelitian, responden yang memiliki jumlah lebih banyak adalah siswa kelas X1I (63.6\%), jenis kelamin perempuan (77.3\%), yang merupakan gabungan dari siswa kelas XI dan XII. Penilaian disini diantaranya berdasarkan pria dan wanita, setelah dilakukan penelitian pria tidak ada yang berpengaruh pada setiap variabel yang ada, sedangkan wanita sangat berpengaruh pada penerimaan terhadap teknologi, itu terdapat pengaruh yang signifikan. Dan juga Penilaian disini menggunakan tingkatan/kelas, yaitu XI dan XII, setelah dilakukan penelitian tingkatan/kelas XI tidak ada yang berpengaruh pada setiap variabel yang ada, sedangkan tingkatan/kelas XII sangat berpengaruh pada penerimaan terhadap teknologi, itu terdapat pengaruh yang signifikan.
\end{abstract}

Kata kunci: Technology Acceptance Model (TAM), Dropbox, Moderation, Gender/Sex, Level/Class, cloud computing (cloud storage).

\begin{abstract}
One new technology is experiencing rapid development of cloud computing technology (cloud storage). SMK Setia Negara Depok is a vocational school that promotes the development and use of information technology for teaching and learning activities of students. Therefore, the school felt it necessary to introduce storage media and data sharing to students that there are no obstacles to the completion of the task, the Dropbox application. The model used on the Technology Acceptance Model $(T A M)$ to include two external variables, namely the CSE and TT and 4 receiving variable PEOU, PU, ATT and IU to determine the Dropbox application of technology acceptance. Some factors that may affect or moderation between gender / sex and level / grade. Sampling using a questionnaire with 176 respondents. Data processing method using Structural Equation Model (SEM) using AMOS 18.0. From the results that have been obtained that the student / i SMK Setia Negara Depok is quite ready and accept the Dropbox application of technology to be used to complete the task group of students described through a causal relationship to the index admission Dropbox application technology in vocational Setia Negara. The number of respondents is 176 Judging from identity respondents in the study, respondents who had more number is X1I grade students (63.6\%), female gender (77.3\%), which is a combination of class XI and XII. Assessment herein which are based on men and women, after research man no effect on any existing variable, while the women are very influential in the acceptance of the technology, it's a significant difference. And also here using the assessment levels / classes, XI and XII, after the research stage / grade XI no effect on any existing variable, while the levels / class XII greatly affect the acceptance of the technology, it's a significant difference.
\end{abstract}

Keywords: Technology Acceptance Model (TAM), Dropbox, Moderation, Gender/Sex, Level/Class, cloud computing (cloud storage). 


\section{PENDAHULUAN}

Seiring dengan perkembangan Teknologi Informasi (TI) banyak aspek kehidupan yang memanfaatkan Teknologi Informasi (TI), salah satu teknologi baru yang mengalami perkembangan pesat adalah teknologi cloud computing. Proses perkembangan Teknologi Informasi (TI) ini terdiri dari perangkat hardware dan perangkat lunak. Semua itu dalam rangka membantu dan penunjang proses belajar mengajar di dunia pendidikan. SMK Setia Negara Depok adalah sekolah kejuruan yang mengutamakan perkembangan teknologi informasi dan memanfaatkannya untuk kegiatan belajar mengajar peserta didik.

Penggunaan aplikasi Dropbox ini menimbulkan reaksi pada diri penggunanya, yaitu berupa penerimaan maupun penolakan. Karena kesuksesan penerapan teknologi informasi sangat tergantung pada penerimaan oleh user sebagai pengguna teknologi (Novita , 2011). Penelitian ini dilakukan untuk mengetahui tingkat penerimaan teknologi aplikasi Dropbox di SMK Setia Negara Depok yang diidentifikasi melalui persepsi dan perilaku pengguna dalam menggunakan teknologi tersebut. Pengukuran perilaku pengguna dalam menggunakan teknologi dianggap penting karena dapat dijadikan tolak ukur keberhasilan penerapan suatu teknologi. Penelitian ini dibatasi pada penerimaan teknologi aplikasi Dropbox, dengan pengembangan model TAM yang menambahkan 2 variable eksternal (variabel CSE (Computer Self-Efficacy) dan variable TT (Techonology Trust)) dan 2 variabel moderasi (variabel Gender/Jenis Kelamin dan variabel Tingkatan/Kelas). Tempat penelitian yang dijadikan uji sample adalah SMK Setia Negara Depok dan kegiatan ini dilakukan pada tahun 2012. Metode analisis yang digunakan adalah Structural Equation Modeling (SEM), serta data-data yang dapat dari penelitian akan diproses menggunakan software AMOS 18.

\section{LANDASAN TEORI}

\subsection{Cloud Computing}

Cloud computing adalah teknologi yang memanfaatkan layanan internet menggunakan pusat server yang bersifat virtual dengan tujuan untuk menjaga/mengolah data dan aplikasi (Mas'at dan Moedjiono,2012). "Cloud Computing adalah gabungan antara pemanfaatan teknologi komputer ('komputasi') dengan pengembangan berbasis Internet ('awan')" (Anonim, 2012). Cloud computing memiliki 3 jenis layanan, yaitu Infrastructure as a Service (IaaS), Platform as a Service (PaaS), dan Software as a Service (SaaS). Cloud Computing adalah suatu konsep umum trend teknologi terbaru lain yang di kenal luas mencakup SaaS. SaaS memberikan kemudahan bagi pengguna untuk bisa memanfaatkan sumber daya perangkat lunak dengan cara berlangganan via web, pengguna dapat langsung menggunakan fitur yang disediakan oleh penyedia layanan (Anonim, 2012).

\subsection{Cloud Storage}

Terdapat 6 struktur cloud computing yang terdiri dari (1) Cloud Client (2) Cloud Services (3) Cloud Applications (4) Cloud Platform (5) Cloud Storages (6) Cloud Infrastructure (Anonim,2012). Salah satu layanan yang di sediakan dari struktur Cloud Computing yaitu Cloud Storages selengkapnya terdapat pada gambar 1 dibawah ini.

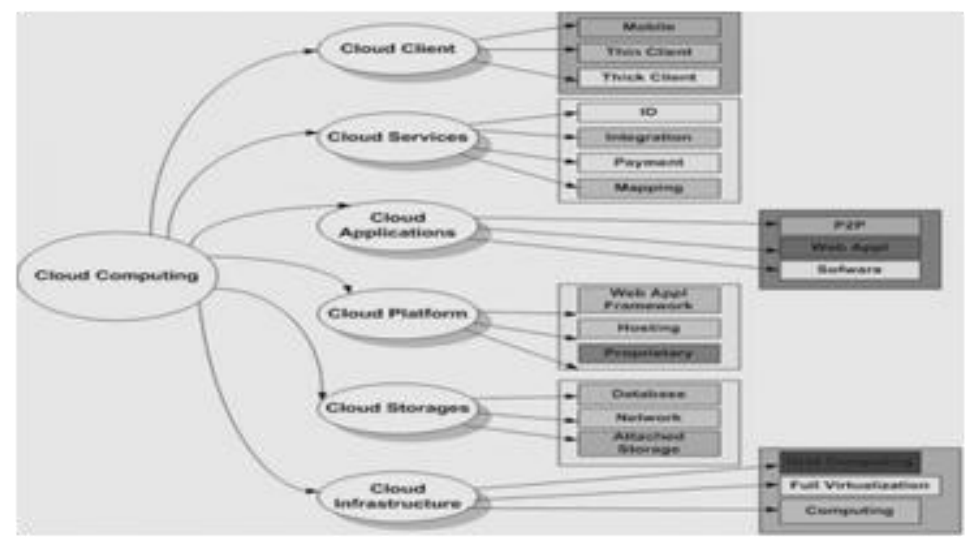

Gambar 1. Struktur Cloud Computing [1] 
Cloud Storages adalah layanan penyimpanan file di internet yang mana file yang disimpan disitu dapat dikelola dari mana saja selama penggunanya terhubung ke cloud storage tersebut melalui internet. Konsep cloud storages sama seperti konsep file server pada suatu kantor perusahaan, hanya saja infrastruktur media storage tersebut dikelola oleh provider cloud dan pemanfaatannya dijadikan layanan penyimpanan file yang dapat diakses dari internet.

\subsection{Dropbox}

Dropbox adalah layanan penyedia data berbasis web yang dioperasikan oleh Evenflow, Inc. Dropbox menggunakan sistem penyimpanan berjaringan yang memungkinkan pengguna untuk menyimpan dan berbagi data serta berkas dengan pengguna lain di internet menggunakan sinkronisasi data. Dropbox juga merupakan salah satu penyedia layanan cloud storage yang cukup populer dan termasuk pemain lama dalam bidang ini. Untuk menggunakan layanan cloud storage Dropbox diperlukan install software yag disediakan oleh Dropbox di situsnya untuk dapat didownload gratis dan di install di Windows, Mac, maupun Linux. Setelah menginstall Dropbox, maka di komputer akan ada folder khusus milik Dropbox.

\subsection{Theory of Reasoned Action (TRA)}

Theory of Reasoned Action (TRA) yang dikembangkan oleh Icek Ajzen dan Martin Fishbein tahun 1980. Teori ini diturunkan dari penelitian-penelitian sebelumnya yang dimulai dari teori sikap (theory of attitude) yang mempelajari tentang sikap (attitude) dan perilaku (behavior) [5]. Teori tindakan beralasan (Theory of Reason Action) adalah teori yang menjelaskan bahwa minat dari seseorang untuk melakukan (atau tidak melakukan) suatu perilaku merupakan penentu langsung dari tindakan atau perilaku [5].

TRA menjelaskan bahwa perilaku (behavior) dilakukan karena individual mempunyai minat atau keinginan untuk melakukannya (behavioral intention) dan minat perilaku (behavioral intention) akan menentukan perilakunya (behavior). ). Minat - minat tersebut merupakan suatu fungsi dari dua penentu dasar, yang satu berhubungan dengan faktor pribadi adalah sikap terhadap perilaku (attitude toward the behavior) individual dan berhubungan dengan pengaruh social adalah norma subyektif (subjective norm). Sikap terhadap suatu perilaku ditentukan oleh kepercayaan yang kuat tentang perilakunya yang disebut dengan istilah kepercayaan-kepercayaan terhadap perilaku (behavioral belief) dan demikian juga norma subjektif didasari oleh kepercayaan-kepercayaan normatif (normative belief) [5] seperti ditunjukkan pada gambar 2 .

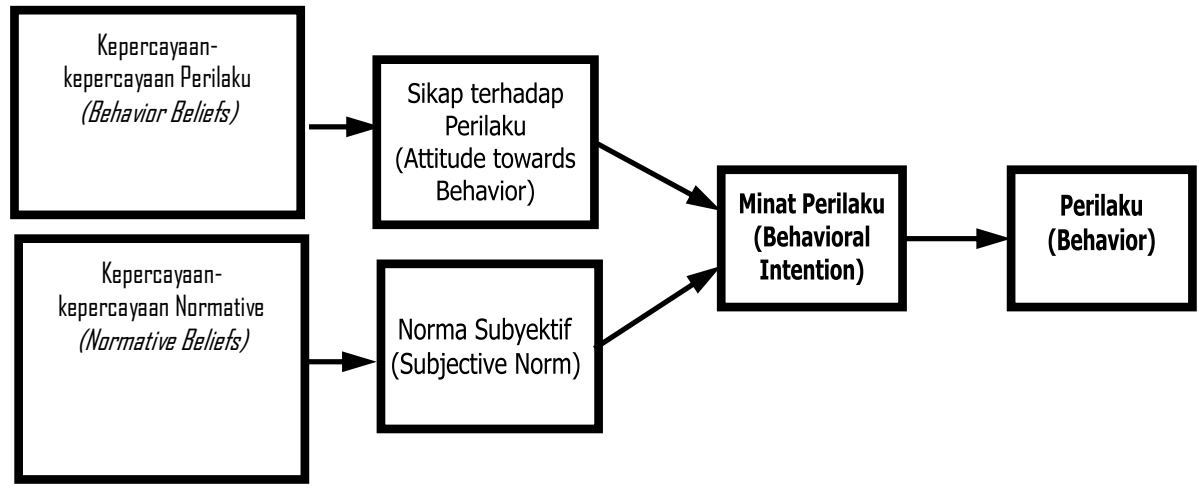

Gambar 2. Theory of Reason Action (TRA)

\subsection{Technology Acceptance Models (TAM)}

Salah satu teori tentang penggunaan system teknologi informasi yang dianggap sangat berpengaruh dan umumnya digunakan untuk menjelaskan penerimaan individual terhadap penggunaan system teknologi informasi adalah model penerimaan teknologi (Technologi Acceptance Model/TAM). Teori ini pertama kali dikenalkan oleh Davis (1989). Teori ini dikembangkan dari Theory of Reasoned Action (TRA) oleh Ajzen dan Fishbein (1980) [5]. Model TAM berasal dari teori psikologis untuk menjelaskan perilaku pengguna teknologi informasi yang berlandaskan pada kepercayaan (beliefs), sikap (attitude), minat (intention) dan hubungan perilaku pengguna (User Behavior Relatioship). Tujuan model ini adalah untuk dapat menjelaskan faktor-faktor utama dari perilaku pengguna teknologi informasi terhadap penerimaan penggunaan teknologi informasi itu sendiri. Model ini akan menggambarkan bahwa penggunaan SI akan dipengaruhi oleh variabel kemanfaatan (Usefullness) dan variabel kemudahan 
pemakaian (Ease of Use), dimana keduanya memiliki determinan yang tinggi dan validitas yang telah teruji secara empiris (DAVIS,1989) untuk lebih jelasnya lihat gambar dibawah ini.

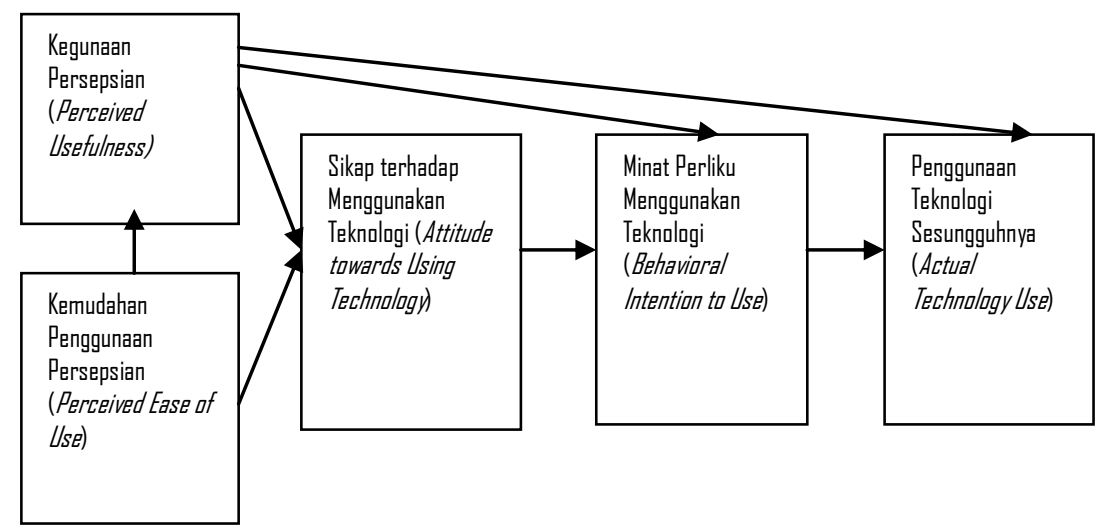

\section{Gambar 3. Technology Acceptance Models (TAM) [5]}

Selanjutnya model TAM yang di uji validitasnya mengalami perkembangan dengan menambah beberapa variable eksternal yang menerangkan lebih lanjut atau menjadi penyebab (antecedent) dari kegunaan persepsian (Perceived usefulness) dan kemudahan penggunaan persepsian (Perceived ease of use) di TAM [5] selengkapnya seperti gambar 4.

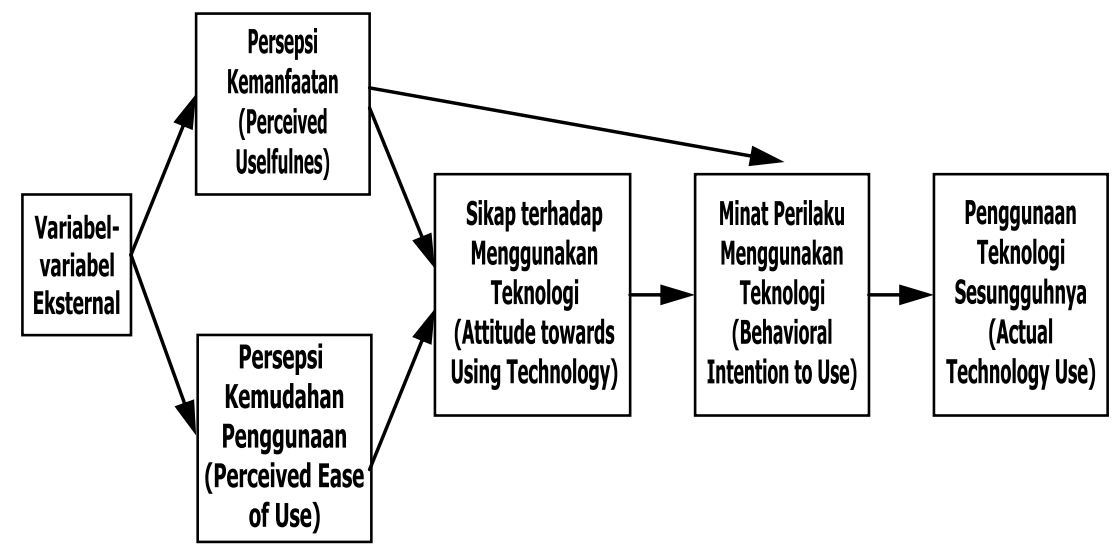

Gambar 4. Technology Acceptance Models (TAM) yang dikembangkan [5]

\subsection{Structural Equation Modeling (SEM)}

Structural Equation Modeling (SEM) merupakan gabungan dari dua metode statistik yang terpisah yaitu analisis faktor (factor analysis) yang dikembangkan di bidang psikologi/psikometri dan model persamaan simultan (Simultaneous Equatiun Modeling) yang dikembangkan di bidang ekonometrika (Ghozali, 2008). Structural Equation Modeling (SEM) merupakan suatu teknik statistik yang mampu menganalisis variabel laten, variabel indikator dan kesalahan pengukuran secara langsung. Dengan menggunakan SEM, memungkinkan untuk dapat menganalisis hubungan antara variabel latel dengan variabel indikatornya, hubungan antara variabel laten yang satu dengan variabel laten yang lainnya, juga dapat diketahui besarnya kesalahan pengukuran.

\subsection{Analysis of Moment Structures (AMOS)}

Amos (Analysis of moment Structure) merupakan salah satu program atau software yang digunakan untuk mengistemasi model pada model persamaan struktural (SEM) (Ghozali, 2008). Amos mengimplementasikan pendekatan yang umum untuk analisa data pada model persamaan struktural yang menjelaskan analisa struktural kovarians, atau kasual modeling. Pendekatan ini meliputi kasus banyak teknik konvensional terkenal, mencakup model linier yang umum dan analysis factor umum. Saat ini software Amos merupakan software yang dapat diandalkan dalam menyelesaikan permasalahan sosial karena kemampuannya dalam mengukur variabel atau tidak dapat diukur secara langsung tetapi dapat diukur melalui indikatornya. 


\subsection{Tinjauan Studi Terdahulu yang Relevan}

1. Kajian Penerimaan Bahasa Pemrogaman Berorientasi Objek Berbasis Open Source Dengan Pendekatan TAM (Technology Acceptance Model) : Study Kasus Universitas Budi Luhur [13].

Penelitian ini dilakukan untuk mengetahui dan menganalisis factor apa saja yang mempengaruhi tingkat penerimaan bahasa pemrograman berorientasi objek berbasis open source di kalangan mahasiswa serta bagaimana hubungan klausal antara factor - factor yang mempengaruhi penerimaan bahasa pemrograman berorientasi objek berbasis open source (Java) di kalangan mahasiswa fakultas teknologi informasi. Pendekatan modelnya dengan menggunakan TAM (Technology Acceptance Model) untuk menggambarkan tingkat penerimaan bahasa pemrograman java di kalangan mahasiswa. Teknik analisis yang digunakan adalah Structural Equation Modeling (SEM), serta datadata yang didapat dari penelitian akan diproses menggunakan software AMOS 16.

Hasil penelitian maka dapat dikatakan bahwa penerimaan penggunaan bahasa pemrograman berorientasi objek berbasis open source dipengaruhi oleh variabel kemudahan (PEOU) dan oleh variabel kemanfaatan $(P U)$. Setelah pengguna merasakan kemudahan dan kemanfaatannya, maka akan meningkatkan sikap penggunaan $(A T U)$ dan minat dalam menggunakan bahasa pemrograman berorientasi objek berbasis open source $(B I T U)$, kemudian akan berpengaruh terhadap perilaku penggunaan $(A S U)$. Artinya semakin mudah bahasa pemrograman berorientasi objek berbasis open source (Java) untuk digunakan maka akan meningkatkan kemanfaatannya.

2. Integrating Trust and Computer Self - Efficacy with TAM : Empirical Assessment of Customers' Acceptanceof Bangking Information Systems (BIS) in Jamaica. [8]

Penelitian ini dilakukan untuk melihat apakah kepercayaan terhadap teknologi dan kemampuan diri terhadap komputer mempengaruhi penerimaan sistem informasi perbankan BIS dengan mencoba memvalidasi integrasi kepercayaan (Trust) dan komputer self-efficacy (CSE). Berdasarkan persamaan struktural pemodelan dengan menggunakan data dari 374 pelanggan dari tiga bank di Jamaika. Peneliti menggunakan moderasi gender/jenis kelamin. Maka dari hasil penelitian ini yang terdiri dari Technology Trust (TT), Computer Self-Efficacy (CSE), sebagai variabel eksternal dan variabel penerimaan yaitu Perceived Ease of Use (PEOU), Perceived Usefulness (PU), Attitude Toward BIS (ATT), Intention to Use BIS (IU) di dapat bahwa TT dan CSE mempengaruhi ke empat variabel penerimaan. Dimana CSE mempengaruhi $T T$.

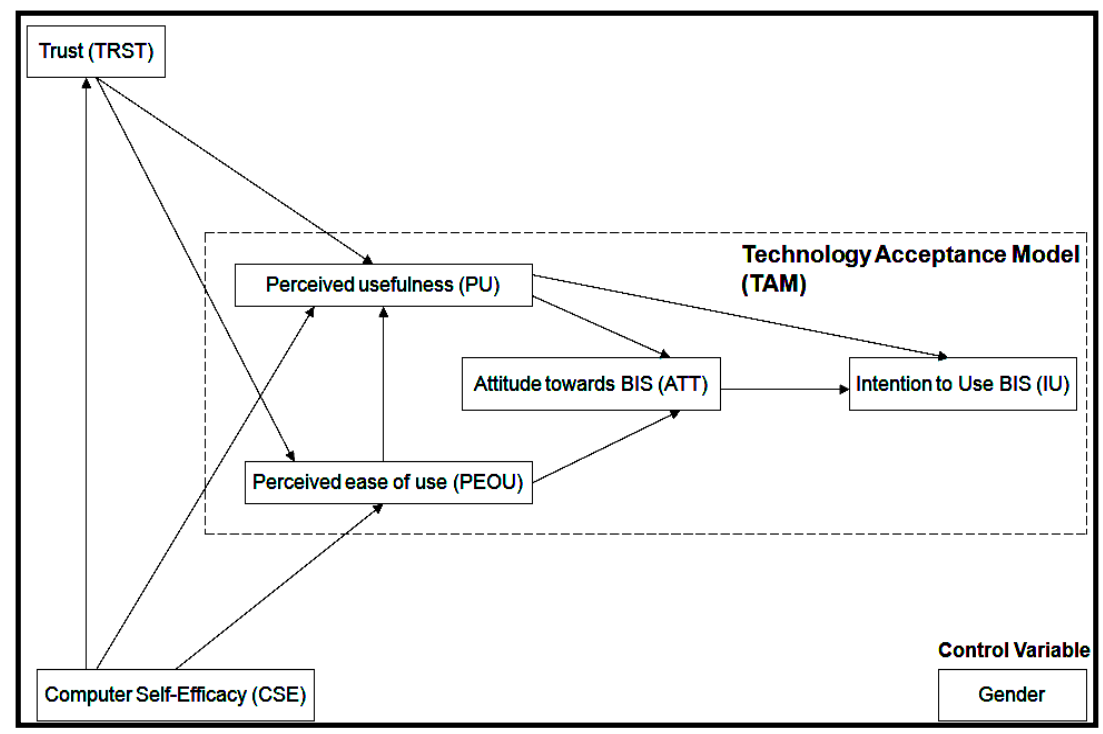

Gambar 5. Model Penelitian Reid dan Levy [8]

\subsection{Kerangka Pemikiran}

Dalam penelitian ini menggunakan faktor ekternal karena adanya perilaku yang tidak diwajibkan (volantory), sehingga diperlukan adanya pengaruh dari luar terhadap penerimaan suatu teknologi baru. Dalam penelitian ini faktor eksternal diambil dari Reid dan Levy (2008) yang menggunakan faktor eksternal TT dan CSE adaptasi dari penelitian kepercayaan (TT) dan CSE yang penting dalam 
menentukan IU sebuah IS ( Compeau, 1999, Gefen, 2003, Tan dan Sutherland, 2004, Wang dan Emurian, 2005) dalam (Reid dan Levy, 2008). Para peneliti juga mengemukakan bahwa pria dan wanita muncul untuk menerima teknologi yang berbeda, maka perbedaan gender tampaknya juga memainkan peran dalam kepercayaan individu, CSE, dan penerimaan mereka terhadap teknologi (Cyr, 2007, Imhof, 2007, Yi, 2006.) dalam (Reid dan Levy, 2008).

Karena penelitian ini bertujuan untuk mengkaji seberapa siap siswa/i SMK Setia Negara Depok menggunakan teknologi yang pada akhirnya akan mempengaruhi perilaku penerimaan mereka terhadap teknologi aplikasi Dropbox. Maka berdasarkan hal tersebut, model penelitian Michael Reid dan Yair Levy di jadikan acuan model dengan penambahan variable moderasi tingkatan/kelas.

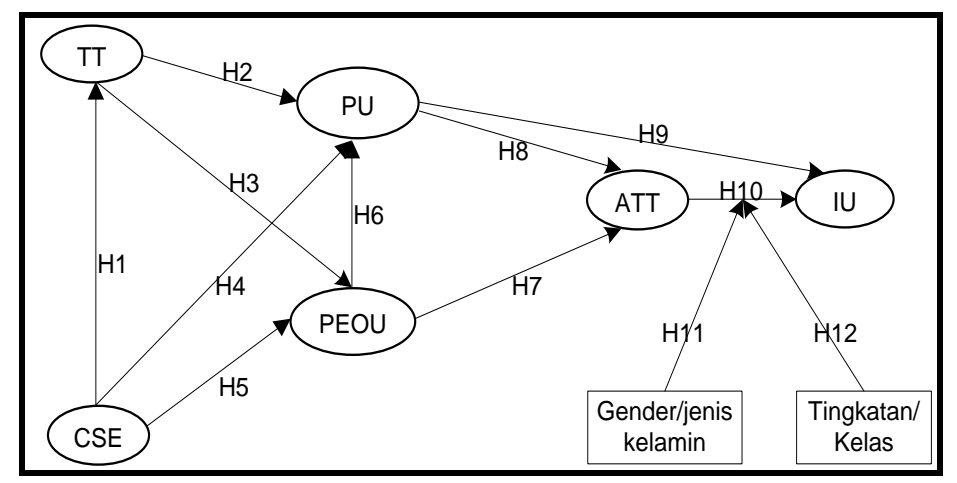

Gambar 6. Technology Acceptance Model (TAM) Penelitian Ini

\subsection{Hipotesis}

Hipotesis-hipotesis dalam penelitian ini meliputi hipotesis umum dan hipotesis khusus.

Hipotesis umum :

$\mathrm{H}_{01} \quad$ : Diduga pengguna aplikasi Dropbox dalam hal ini adalah siswa/i SMK Setia Negara Depok sudah siap menerima teknologi generasi cloud computing aplikasi Dropbox.

$\mathrm{H}_{02}$ : Diduga tidak ada pembedaan antara gender/jenis kelamin dan tingkatan/kelas yang Hipotesis khusus : bersangkutan dalam penerimaan aplikasi Dropbox di SMK Setia Negara Depok.

H1 : Diduga persepsi kemampuan diri terhadap komputer (Computer Self Efficacy/CSE) secara signifikan berpengaruh terhadap kepercayaan teknologi Dropbox (Technology Trust/TT).

H2 : Diduga kepercayaan teknologi Dropbox (Technology Trust/TT) secara signifikan berpengaruh terhadap persepsi kemanfaatan (Perceived Usefulness/PU).

H3 : Diduga kepercayaan teknology Dropbox (Technology Trust/TT) secara signifikan berpengaruh terhadap kemudahan menggunakan Dropbox (Perceived Ease of Use/PEOU).

H4 : Diduga persepsi kemampuan diri terhadap komputer (Computer Self Efficacy/CSE) secara signifikan berpengaruh terhadap persepsi kemanfaatan (Perceived Usefulness/PU).

H5 : Diduga persepsi kemampuan diri terhadap komputer (Computer Self Efficacy/CSE) secara signifikan berpengaruh terhadap kemudahan menggunakan Dropbox (Perceived Ease of Use/PEOU).

H6 : Diduga persepsi kemudahan menggunakan Dropbox (Perceived Ease of Use/PEOU) secara signifikan berpengaruh terhadap persepsi kemanfaatan (Perceived Usefulness/PU).

H7 : Diduga persepsi kemudahan menggunakan Dropbox (Perceived Ease of Use/PEOU) secara signifikan berpengaruh terhadap persepsi sikap terhadap Dropbox (Attitude Towards/ATT.

H8 : Diduga persepsi persepsi kemanfaatan (Perceived Usefulness/PU) secara signifikan berpengaruh terhadap persepsi sikap terhadap Dropbox (Attitude Towards/ATT).

H9 : Diduga persepsi kemanfaatan (Perceived Usefulness/PU) secara signifikan berpengaruh terhadap persepsi sikap niat/keinginan untuk menggunakan Dropbox (Intention to Use/IU).

H10 : Diduga persepsi sikap terhadap Dropbox (Attitude Towards/ATT) secara signifikan berpengaruh terhadap persepsi sikap niat/keinginan untuk menggunakan Dropbox (Intention to Use/IU).

H11 : Diduga jenis kelamin secara signifikan berpengaruh terhadap persepsi sikap terhadap Dropbox (Attitude Towards/ATT) dalam mempengaruhi penerimaan aplikasi Dropbox

H12 : Diduga tingkatan/kelas secara signifikan berpengaruh terhadap persepsi sikap terhadap Dropbox (Attitude Towards/ATT) dalam mempengaruhi penerimaan aplikasi Dropbox 


\section{METODOLOGI}

\subsection{Jenis Penelitian}

Jenis penelitian yang akan dilakukan pada penelitian ini menjelaskan kategori penelitian Explanatory, yaitu penelitian yang berisi pembuktian empiris yang dibangun berdasarkan teori Model Penerimaan Teknologi yang dikembangkan Reid dan Levy (2008) dengan menggunakan model Technology Acceptance Model (TAM). Data yang telah terkumpul di kelompokkan dalam Ms. Exel dan di export ke dalam software statistic SPSS 17.00. Setelah itu diuji menggunakan salah satu software dalam hal ini adalah AMOS 18

\subsection{Populasi dan Sampel Penelitian}

Dalam penelitian ini data di peroleh berdasarkan populasi dan sampel. Populasi dalam penelitian ini di peroleh dari siswa/i yang berada di lingkungan SMK Setia Negara Depok, di antaranya kelas XI dan XII sejumlah 176 siswa/i yang terdiri dari 64 siswa/i kelas XI dan 112 siswa/i kelas XII. Sampel yang di ambil berdasarkan rekomendasi dari Hair (1996), yaitu jumlah sampel minimal untuk SEM sebanyak 100 - 200 responden. Teknik yang di gunakan dalam pengambilan sampel adalah Purposive Sampling yaitu pengambilan sampel yang tidak di pilih secara acak dan unsur populasi yang terpilih menjadi sampel disebabkan karena sudah direncanakan oleh peneliti.

\subsection{Metode Pengumpulan Data}

Penelitian ini melalui beberapa tahap dalam pengembangannya yaitu:

a. Studi keputakaan, Data sekunder dalam penelitian ini adalah dengan melakukan pengumpulan data bersifat teoritis. Pengambilan data tersebut dilakukan dengan cara mempelajari literatur-literatur, jurnal-jurnal penelitian, dan sumber-sumber lain yang ada hubungannya dengan permasalahan yang dibahas. Penulisan pustaka menggunakan System Harvard Referencing Standard. Semua yang tertera dalam daftar pustaka harus di rujuk dalam tulisan atau paper.

b. Kuesioner. Data primer dalam penelitian ini adalah kuesioner. Pengumpulan data dilakukan melalui kuesioner bersifat closed question dimana responden dapat dengan cepat dan mudah menjawab kuesioner. Metode yang digunakan untuk mendapatkan data empiris melalui kuesioner berskala semantic diferensial atau skala interval yang digunakan untuk mengukur sikap tidak dalam bentuk pilihan ganda atau checklist, tetapi tersusun dari sebuah garis continue, nilai yang Sangat negative terletak dikiri sedangkan yang sangat prositif terletak di sebelah kanan. Dimulai dari STS untuk penyataan Sangat Tidak Setuju sampai SS untuk pernyataan Sangat Setuju, point juga terdapat diantara ruas, yaitu 1 dan 6. Seperti gambar dibawah ini.

Tabel 1. Contoh kuesioner dengan skala semantic diferensial

\begin{tabular}{llll}
\hline \multicolumn{1}{c}{ Pernyataan } & Pendapat \\
\hline $\begin{array}{l}\text { Saya dapat menginstal komputer dengan } \\
\text { sangat baik }\end{array}$ & komputer & Saya dapat menjalankan \\
dengan sangat baik & & ST & SS \\
\hline
\end{tabular}

\subsection{Instrumen Penelitian}

Penelitian ini menggunakan instrument kuesioner yang dibuat dengan menggunakan closed questions agar responden di SMK Setia Negara Depok dapat dengan mudah menjawab kuesioner dan data dari kuesioner tersebut dengan cepat dianalisis secara statistic, serta pernyataan yang sama dapat diulang dengan mudah. Kuesioner pada penelitian ini dibuat dengan menggunakan skala Semantic Differential. Hasil kuesioner berupa data, akan disimpan dalam format excel dan langsung digunakan sebagai data mentah untuk analisa dengan software AMOS 18. Indikator-indikator yang digunakan dalam penelitian ini dapat dilihat pada Tabel 2. 
Tabel 2. Indikator pengukuran penerimaan Aplikasi Dropbox

\begin{tabular}{|c|c|c|}
\hline Variabel & Indikator & Jumlah Item \\
\hline Computer Self Efficacy / & 1. Menginstal software pada komputer & 1 \\
\hline Kemampuan diri pada & 2. Menjalankan Dropbox & 1 \\
\hline komputer (CSE) & $\begin{array}{l}\text { 3. Men-download file dari Dropbox dan } \\
\text { menyimpannya ke dalam harddisk/ flashdisk. }\end{array}$ & 1 \\
\hline \multirow{2}{*}{$\begin{array}{l}\text { (Marakas, } 1998 \text { dalam } \\
\text { Maria, 2010) }\end{array}$} & 4. Meng-upload file dari Dropbox & 1 \\
\hline & $\begin{array}{l}\text { 5. Mengoperasikan fitur Dropbox seperti sharing } \\
\text { data, get link, upload picture }\end{array}$ & 1 \\
\hline \multirow{2}{*}{$\begin{array}{l}\text { Technology Trust / } \\
\text { Kepercayaan teknologi } \\
\text { (TT) }\end{array}$} & $\begin{array}{l}\text { 6. Mampu menyelesaikan permasalahan yang } \\
\text { rumit }\end{array}$ & 1 \\
\hline & $\begin{array}{l}\text { 7. Dapat digunakan untuk mengerjakan tugas } \\
\text { kelompok }\end{array}$ & 1 \\
\hline \multirow{3}{*}{$\begin{array}{l}\text { (Reid dan Levy, 2008) } \\
\text { (Nah, 2004 dalam } \\
\text { Sonny, 2011) }\end{array}$} & 8. Dapat diandalkan & 1 \\
\hline & 9. Mempunyai kecepatan & 1 \\
\hline & 10. Mempunyai keamanan & 1 \\
\hline \multirow{3}{*}{$\begin{array}{l}\text { Perceived Ease of Usel } \\
\text { Persepsi Kemudahan } \\
\text { Penggunaan (PEOU) }\end{array}$} & 11. Mudah untuk dipahami & 1 \\
\hline & 12. Mudah untuk dipelajari & 1 \\
\hline & 13. Mudah untuk digunakan & 1 \\
\hline \multirow{2}{*}{$\begin{array}{l}\text { (Davis (1989) dalam } \\
\text { Maria, 2010) }\end{array}$} & 14. Mudah untuk dioperasikan & 1 \\
\hline & 15. Kemudahan membuat jadi terampil & 1 \\
\hline \multirow{3}{*}{$\begin{array}{l}\text { Perceived Usefulness / } \\
\text { Persepsi Kemanfaatan } \\
\text { (PU) }\end{array}$} & 16. Mempercepat pekerjaan & 1 \\
\hline & 17. Meningkatkan produktifitas & 1 \\
\hline & 18. Meningkatkan efektifitas & 1 \\
\hline \multirow{2}{*}{$\begin{array}{l}\text { (Darsono, 2005) } \\
\text { (Maria, 2010) }\end{array}$} & 19. Mempermudah manajemen & 1 \\
\hline & $\begin{array}{l}\text { 20. Membantu dalam mengedit dan berbagi } \\
\text { dokumen }\end{array}$ & 1 \\
\hline \multirow{3}{*}{$\begin{array}{l}\text { Attitude Towards/ } \\
\text { Sikap Terhadap (ATT) }\end{array}$} & 21. Menikmati penggunaan & 1 \\
\hline & 22. Rasa memperoleh manfaat & 1 \\
\hline & 23. Mendukung tugas & 1 \\
\hline \multirow{4}{*}{$\begin{array}{l}\text { (Michael dan Yair, } \\
\text { 2008) }\end{array}$} & 24. Ide yang baik dalam penggunaan & 1 \\
\hline & 25. Hal yang positif yang baik dalam penggunaan & 1 \\
\hline & 26. Merasa Puas terhadap cara kerja & 1 \\
\hline & 27. Rasa untuk menerima & 1 \\
\hline \multirow{4}{*}{$\begin{array}{l}\text { Intention to Use/ } \\
\text { Niat/keinginan untuk } \\
\text { menggunakan (IU) } \\
\text { (Michael dan Yair, } \\
\text { 2008) }\end{array}$} & 28. Niat untuk menggunakan & 1 \\
\hline & 29. Niat untuk meningkatkan penggunaan & 1 \\
\hline & 30. Memotivasi pengguna lain & 1 \\
\hline & Total & 30 \\
\hline
\end{tabular}

\subsection{Teknik Analisis Data}

\subsubsection{Analisis Statistik Deskriptif}

Tujuan analisis ini memberikan gambaran atau berbasis suatu data berupa rata-rata, standar deviation, variance, maksimum, minimum, kurtosis (puncak dari distribusi data) dan skewness (kemencengan distribusi data) (menggunakan SPSS Statistics 17.0 ) dari indikator - indikator variabel persepsi kemampuan diri terhadap komputer (Computer Self Efficacy/CSE), kepercayaan terhadap teknologi (Teknology Trust/TT), persepsi kemudahan menggunakan (Perceived Ease of Use/PEOU), persepsi kemanfaatan (Perceived Usefulness/PU), sikap terhadap (Attitude Towards/ATT), niat/keinginan 
untuk menggunakan (Intention to Use/IU) yang di peroleh dari responden dengan sampel kelas XI dan kelas XII yang mempertimbangkan jenis kelamin dan tingkatan/kelas.

\subsubsection{Analisis Statistik Inferensial}

Dalam menguji hipotesis peneliti menggunakan metode statistic multivariate Structural Equation Model (SEM). Tujuan utama analisis statistic inferensial dengan menggunakan SEM adalah untuk memperoleh model yang plausible atau fit (sesuai cocok) dengan masalah yang sedang dikaji pada penelitian ini. Tujuan analisis SEM juga untuk mengetahui hubungan kausal antar variable eksogen atau endogen pada model yang dibangun pada penelitian ini. Pada penelitian ini, model berbasis teori yang dikembangkan merupakan adopsi penerimaan teknologi penelitian Michael Reid dan Yair Levy (2008). Pada penelitian ini terdapat 1 (satu) konstruk eksogen dan 5 (lima) konstruk endogen dengan menggunakan 2 (dua) variabel moderasi. Konstruk eksogen adalah variabel yang tidak dapat diprediksi atau tidak dipengaruhi oleh variabel lain. Pada model meliputi :

a. Computer Self Efficacy (kemampuan diri terhadap komputer).

Sedangkan konstruk endogen atau disebut variabel dependen yaitu variabel yang dipengaruhi atau yang menerima akibat karena adanya variabel endogen. Pada model meliputi :

a. Technology Trust (kepercayaan teknologi).

b. Perceived Ease of Use (persepsi kemudahan penggunaan).

c. Perceived of Usefulness (persepsi kemanfaatan).

d. Attitude Towards (sikap terhadap).

e. Intention to Use (niat/keinginan untuk menggunakan).

Variabel moderasi adalah variabel bebas kedua yang sengaja dipilih oleh pene!iti untuk menentukan apakah kehadirannya berpengaruh terhadap hubungan antara variabel bebas pertama dan variabel tergantung. Variabel ini diukur, dimanipulasi atau dipilih peneliti untuk mengetahui apakah variabel tersebut mengubah hubungan antara variabel bebas dan variabel tergantung. Dalam model meliputi :

a. Gender/Jenis Kelamin.

b. Tingkatan/Kelas.

\section{HASIL PENELITIAN DAN PEMBAHASAN}

\subsection{Data Demografi Responden}

Responden dalam penelitian ini adalah 176 siswa/i. Responden telah mengisi kuesioner yang disebarkan secara langsung ke SMK Setia Negara Depok pada tanggal 16 Juli 2012 tahun akademik 2012-2013 semester ganjil.

Tabel 3. Identitas Responden

\begin{tabular}{|c|c|c|}
\hline Klasifikasi Responden & Jumlah & Persentase \\
\hline \multicolumn{3}{|l|}{ Tingkatan Kelas } \\
\hline Kelas XI: & 64 & $36.4 \%$ \\
\hline Kelas XII: & 112 & $63.6 \%$ \\
\hline Jumlah: & 176 & $100 \%$ \\
\hline \multicolumn{3}{|l|}{ Jenis Kelamin } \\
\hline Laki-laki: & 40 & $22.7 \%$ \\
\hline Perempuan: & 136 & $77.3 \%$ \\
\hline Jumlah & 176 & $100 \%$ \\
\hline
\end{tabular}

Ditinjau dari indentitas responden pada penelitian, responden yang memiliki jumlah lebih banyak adalah siswa kelas X1I (63.6\%), jenis kelamin perempuan (77.3\%), yang merupakan gabungan dari siswa kelas XI dan XII. 


\subsection{Pengujian Model Berbasis Teori}

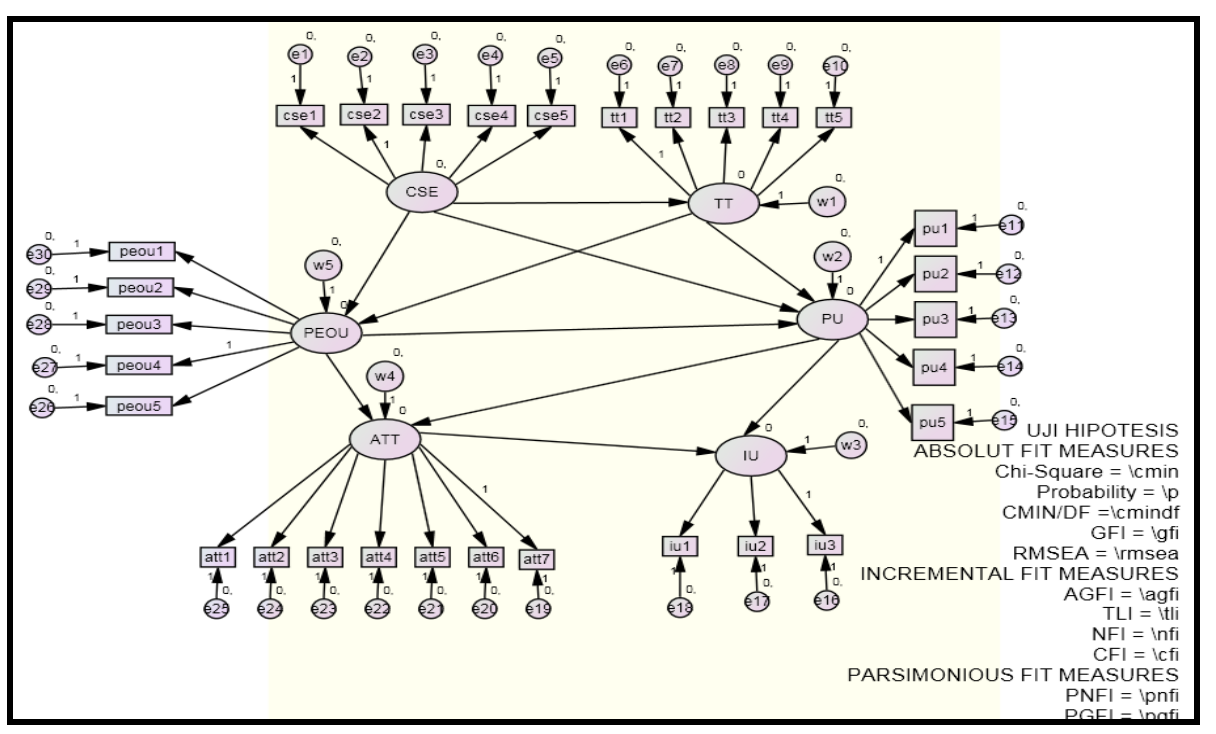

Gambar 7. Model Awal Penelitian

\subsubsection{Uji Validitas}

Pada tahap ini akan diuji kemampuan suatu indikator sehingga dapat mewakili suatu konstruk. Untuk mengukur validitas konstruk dapat dilihat dari nilai loading factor yang merupakan nilai dari standardized regression. Pengujian dilakukan dengan analisis model Confirmatory Factor Analysis (CFA) terhadap konstruk eksogen dan endogen.

a. Uji validitas konstruk eksogen

1) Kemampuan diri terhadap komputer/ CSE

b. Uji validitas konstruk endogen

1) Kepercayaan terhadap teknologi /TT

2) Persepsi Kemudahan untuk Penggunaan/ PEOU

3) Persepsi Kemanfaatan/ PU

4) Sikap Terhadap/ ATT

5) Niat/Keinginan untuk Menggunaan/IU

\subsubsection{Uji Realibilitas}

Construct reliability menyatakan ukuran konsistensi internal dari indikator-indikator sebuah konstruk yang menunjukkan derajat sampai dimana masing-masing indikator tersebut mengidentifikasikan sebuah konstruk/laten yang umum. Sedangkan variance extracted menunjukkan indikator-indikator telah mewakili secara baik konstruk/ laten yang dikembangkan. Cut-off value dari construct reliability adalah minimal 0,70 sedangkan Cut-off value dari variance extracted minimal 0,50 [3]

Tabel 4. Uji Reliabilitas Gabungan

\begin{tabular}{ccc}
\hline Konstruk & Construct Reliability & Variance Extracted \\
\hline CSE & 0.883 & 0.607 \\
TT & 0.930 & 0.726 \\
PEOU & 0.924 & 0.711 \\
PU & 0.955 & 0.809 \\
ATT & 0.976 & 0.851 \\
IU & 0.930 & 0.816 \\
\hline
\end{tabular}

Dari tabel tersebut di atas dapat disampaikan bahwa seluruh konstruk variabel laten memenuhi syarat cut-off value untuk contruct reliability yaitu memiliki nilai $>0,70$. Dengan demikian dapat dikatakan bahwa masing-masing variabel memiliki reliabilitas yang baik. 


\subsubsection{Uji Kesesuaian Model}

Untuk menyatakan suatu model fit (diterima) atau tidak, perlu dilakukan uji model secara menyeluruh guna mengukur kesesuaian antara matriks varians kovarians sampel (data observasi) dengan matriks varians kovarians. Kriteria utama sebagai dasar pengambilan keputusan adalah; jika probability (P) $\geq 0,05$ maka matriks varians-kovarians sampel sama (tidak berbeda) dengan matriks varians-kovarians populasi dugaan, artinya model fit. Sebaliknya jika nilai $\mathrm{P}<0,05$ maka model tidak fit.

Hasil uji kesesuaian model diketahui nilai Probability (P) pada tabel 9 kurang dari nilai yang direkomendasikan, yaitu kurang dari 0,05 . Hal ini berarti model teori yang diajukan pada penelitian ini tidak sesuai dengan model populasi yang diobservasi. Uji kesesuaian ini hanya berlaku untuk sample. Seperti tabel dibawah ini .

Tabel 5. Hasil Uji Kesesuaian Model

\begin{tabular}{|c|c|c|c|}
\hline Ukuran Kesesuaian & Batas nilai kritis & Hasil Uji Model & Keterangan \\
\hline \multicolumn{4}{|c|}{ Absolut Fit Measures } \\
\hline Chi-Square $X^{2}$ & $\begin{array}{l}\text { Kecil, } X^{2} \text { hitung } \leq \\
X^{2} \text { tabel }\end{array}$ & 1924.285 & Tidak Baik \\
\hline Probability & $\geq 0,05$ & 0.000 & Marginal \\
\hline CMIN/DF & $\leq 2.00$ & 4.872 & Tidak Baik \\
\hline GFI & $\geq 0,90$ & - & Tidak Baik \\
\hline RMSEA & $\leq 0,08$ & 0.167 & Tidak Baik \\
\hline \multicolumn{4}{|c|}{ Incremental Fit Measures } \\
\hline AGFI & $\geq 0,90$ & - & Tidak Baik \\
\hline TLI & $\geq 0,95$ & 0.745 & Marginal \\
\hline NFI & $\geq 0,90$ & 0.727 & Marginal \\
\hline $\mathrm{CFI}$ & $\geq 0,95$ & 0.769 & Marginal \\
\hline \multicolumn{4}{|c|}{ Parsimonious Fit Measures } \\
\hline PNFI & $\geq 0,60$ & 0.660 & Baik \\
\hline PGFI & $\geq 0,60$ & - & Tidak Baik \\
\hline
\end{tabular}

Berdasar tabel diatas karena nilai P tidak memenuhi persyaratan, maka uji kriteria lain seperti; absolut fit measure, incremental fit measures, dan parsimonious fit measures tidak dilanjutkan. Langkah selanjutnya dalam penelitian ini adalah menggunakan analisis jalur (path analysis).

\subsubsection{Uji Signifikansi}

Berdasarkan hasil uji signifikasi (model penelitian diagram jalur, hubungan antar variabel dalam penelitian ini terlihat dalam gambar 8 dan tabel 6 .

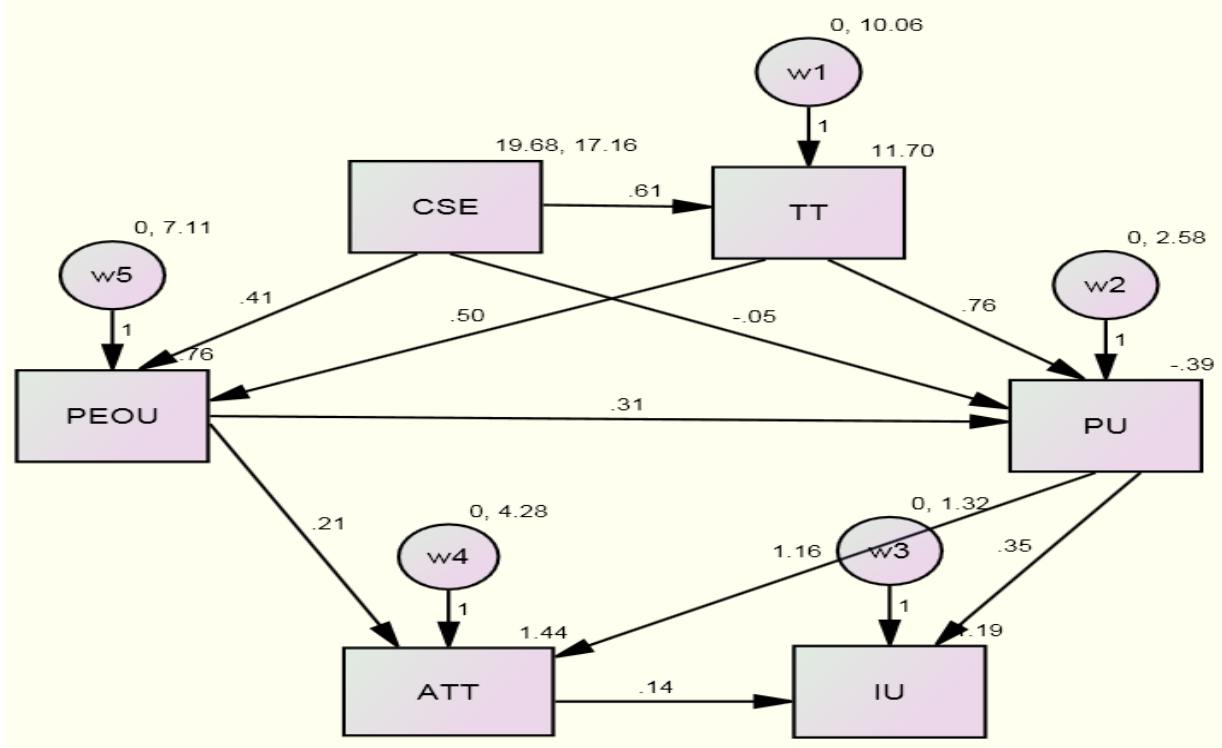

Gambar 8. Hasil Uji Signifikansi Model Jalur Awal 
Tabel 6. Uji Signifikansi Model Jalur Awal

\begin{tabular}{lllrc}
\hline & & & Kofisien Regresi & $\boldsymbol{P}$ \\
\hline TT & $<--$ & CSE & .606 & $* * *$ \\
PEOU & $<---$ & TT & .500 & $* * *$ \\
PEOU & $<---$ & CSE & .408 & $* * *$ \\
PU & $<---$ & TT & .757 & $* * *$ \\
PU & $<---$ & PEOU & .307 & $* * *$ \\
PU & $<---$ & CSE & -.051 & .278 \\
ATT & $<---$ & PEOU & .211 & .001 \\
ATT & $<---$ & PU & 1.163 & $* * *$ \\
IU & $<---$ & PU & .355 & $* * *$ \\
IU & $<---$ & ATT & .142 & .002 \\
\hline
\end{tabular}

Didapatkan pula hasil dari hipotesis operasional yang telah dibuat sebelumnya, yaitu seperti yang tertera pada tabel diatas ini dimana hipotesis $\mathrm{H}_{1}$ diterima apabila nilai $\mathrm{P}<0.05$ sedangkan hipotesis $\mathrm{H}_{1}$ ditolak apabila nilai $\mathrm{P} \geq 0.05$. Setelah dilakukan uji signifikansi, dan telah ditentukan variabel yang digunakan dan yang di keluarkan, maka didapatkan model akhir penelitian seperti pada gambar 9 .

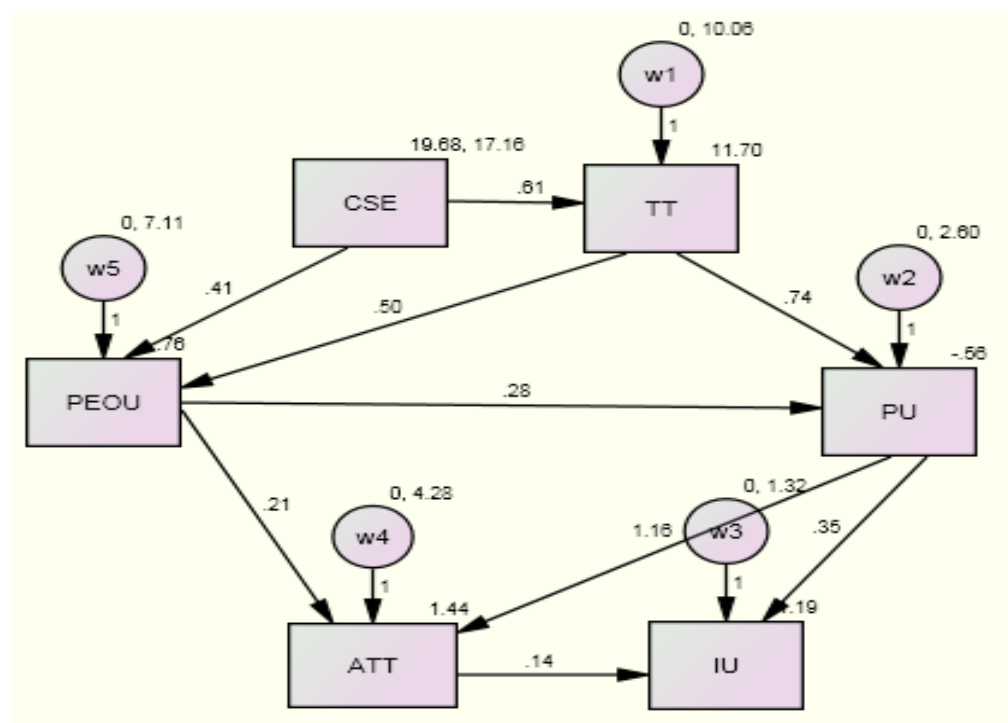

Gambar 9. Model Jalur Akhir

\subsection{Pembahasan}

\subsubsection{Interpretasi Model}

Setelah dilakukan uji signifikasi, maka dilanjutkan dengan membuat persamaan model akhir. Persamaan dari variabel endogen model akhir diperlihatkan seperti dibawah ini:

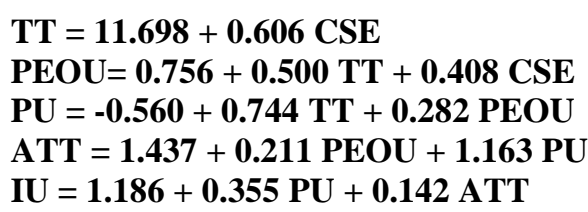

Berdasarkan modifikasi model dan hasil pengujian hipotesis, maka dapat dijelaskan bahwa model yang didapatkan pada penelitian ini adalah seperti gambar 10 . 


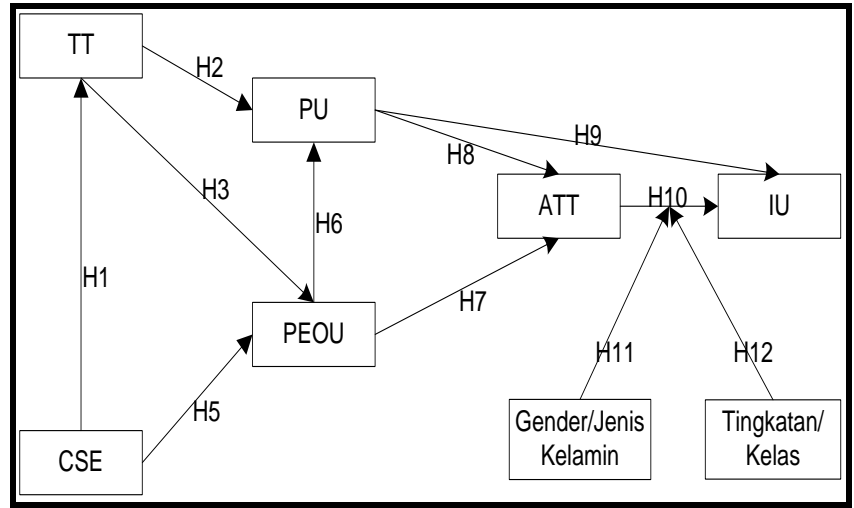

Gambar 10. Technology Acceptance Model (TAM) Akhir Penelitian

Berdasarkan model di atas, maka dapat di katakan bahwa penerimaan teknologi aplikasi Dropbox dipengaruhi oleh variabel eksternal CSE dan TT. Setelah pengguna yakin punya kemampuan menggunakan komputer dan percaya akan teknologi maka akan meningkat apakah teknologi tersebut bermanfaat (PU) dan mudah dalam penggunaan (PEOU) sehingga menimbulkan sikap terhadap teknologi (ATT) yang akan berpengaruh pada niat/keinginan dalam mengunakan (IU).

\section{KESIMPULAN}

\subsection{Kesimpulan}

1. Para siswa/i SMK Setia Negara Depok sudah cukup siap dan menerima teknologi aplikasi Dropbox untuk digunakan menyelesaikan tugas kelompok siswa yang dijelaskan melalui hubungan kausal indeks terhadap penerimaan teknologi aplikasi Dropbox di SMK Setia Negara.

2. Dari hasil model akhir penelitian dapat di lihat faktor - faktor yang mempengaruhi penerimaan teknologi aplikasi Dropbox melalui hubungan kausal indeks terhadap penerimaan teknologi aplikasi Dropbox di SMK Setia Negara sebagai berikut :

a. Berdasarkan analisis sub-grup model moderating keragaman jenis kelamin dan tingkatan/kelas dapat ditarik kesimpulan yaitu :

1) Penilaian disini menggunakan jenis kelamin, yaitu pria dan wanita, setelah dilakukan penelitian pria tidak ada yang berpengaruh pada setiap variabel yang ada, sedangkan wanita sangat berpengaruh pada penerimaan terhadap teknologi, itu terdapat pengaruh yang signifikan.

2) Penilaian disini menggunakan tingkatan/kelas, yaitu XI dan XII, setelah dilakukan penelitian tingkatan/kelas XI tidak ada yang berpengaruh pada setiap variabel yang ada, sedangkan tingkatan/kelas XII sangat berpengaruh pada penerimaan terhadap teknologi, itu terdapat pengaruh yang signifikan.

b. Model yang diajukan dalam penelitian ini yaitu model penerimaan teknologi (Technology Acceptance Model) tidak sepenuhnya terbukti secara empiris dalam penelitian penerimaan aplikasi Dropbox dalam pekerjaan kelompok siswa di SMK Setia Negara. Oleh karena itu maka kesimpulan dari hasil penelitian ini hanya berlaku untuk sampel penelitian yaitu pengguna teknologi aplikasi Dropbox untuk penyelesaian pekerjaan kelompok siswa di SMK Setia Negara Depok.

\section{DAFTAR PUSTAKA}

[1] Anonim. (2012). Layanan Cloud Storage [http://www.cloudindonesia.or.id/layanan-cloudstorage.html] (Akses 2 Juli 2014)

[2] Anonim. (2012). Pengertian Dropbox [http://id.wikipedia.org/wiki/Dropbox] (Akses 2 Juli 2014)

[3] Ghozali. (2008). Model Persamaan Struktural: Konsep dan Aplikasi dengan program AMOS 16.0. Semarang : Badan Penerbit Universitas Diponegoro.

[4] Hair, J., Rolph E.A., Ronald L.T., Wiliam C.B. (1998). Multivariate Data Analysis with Readings ( $4^{\text {th }}$ ed.). Englewood, New Jersey: Prentice Hall.

[5] Jogiyanto. (2007), Sistem Informasi Keperilakuan. Yogyakarta: Andi. 
[6] Mas'at, A dan Moedjiono. (2012). "Strategi penerapan cloud computing pada sistem diseminasi meteorologi, klimatologi, kualitas udara, dan geofisika (MKKUG)", Universitas Budi Luhur, Jakarta.

[7] Nah, F.F.H., Tan, X, The, S.H. (2004), An Empirical investigation on end-users' acceptance of enterprise system, dalam Information Resources Management Journal Vol.l7, NO.3.

[8] Reid, M dan Levy, Y. (2008). "Integrating Trust and Computer Self-Efficacy with TAM: An Empirical Assessment of Customers' Acceptance of Banking Information System (BIS) in Jamaica".

[9] Rogers, M.E. (1986). "Communication Technology- The New Media in Society, The Free Prees, A. Dursion of Macmillin, Inc.”, New York,1986 [http://syopian.net/blog/?p=1088] (Akses 31 Juni 2015)

[10] ---------. (2011). Structural Equation Modeling (SEM) Konsep \& Aplikasi dengan AMOS 18. Jakarta: Elex Media Komputindo

[11] Wangpipatwong, S., Chutimaskul,W., dan Papasratorn B., (2008). “Understanding Citizen's Continuance Intention to Use e-Government Wensite : a Composite View of Technology Acceptance Model and Computer Self-Efficacy", Thailand.

[12] Fatonah, N.S. (2012). Kajian Efektivitas E-Learning Dalam Mendukung Proses Belajar Mengajar: Studi Kasus Universitas Mercubuana. Tesis Magister Komputer Program Pascasarjana Universitas Budi Luhur: Jakarta

[13] Novita, I. (2011). "Kajian Penerimaan Bahasa Pemrograman Bahasa Pemrograman Berorientasi Objek Berbasis Open Source Dengan Pendekatan TAM (Technology Acceptance Model): Studi Kasus Universitas Budi Luhur", Universitas Budi Luhur, Jakarta. 